\title{
A Comprehensive Insight into Lean Management: Literature Review and Trends
}

\author{
Neena Sinha (iD, Misha Matharu \\ Guru Gobind Singh Indraprastha University (India) \\ dr.neenasinha@gmail.com,misha.matharu@gmail.com
}

Received: March 2019

Accepted: April 2019

\begin{abstract}
:
Purpose: Lean Management has evolved into an inter-disciplinary subject with linkages to Operations Management, Organizational Behaviour, and Strategic Management. The objective of this paper is to review journal articles on lean published in major academic sources with a view to provide taxonomy of the field of lean management facilitating identification of the pertinent themes that exists in literature, while presenting an overview of the main definitions, chronological evolution, diffusion among developed and emerging economies
\end{abstract}

Design/methodology/approach: A review of literature has been conducted which includes 447 research articles in 51 Journals from Academic sources: Emerald Insight, T\&F and Science Direct with main focus on lean management.

Findings: An analysis of the surveyed literature brings to light an exponential increase in number of papers in the last 3 decades. The paper conducted study of lean in 3 phases i.e. Pre 2001, 2001-2010, Post 2010; enabling the study of maturity of lean. Observation regarding diffusion of lean globally reveals that lean has been adopted by both developed and emerging economies with noteworthy tilt towards its adoption in Asian countries in the recent past whereas initially it was confined to developed countries. New themes that have emerged such as Industry 4.0 and sustainability in the context of lean have been identified.

Research limitations/implications: The aim of the paper is succinct representation of the current status and facilitating future research in the field.

Originality/value: The present business environment with its rapid changes in market, rise in its economic, technical, and socio-psychological complexities has paved way for acceptance of lean as an operating strategy in a pervasive manner. The present study extends efforts of previous studies to analyse diffusion of lean globally, themes that have emerged and also includes more contemporary research with focus on its spread to emerging economies.

Keywords: lean management, literature review, emerging economies, asian context, lean diffusion

\section{To cite this article:}

Sinha, N., \& Matharu, M. (2019). A comprehensive insight into lean management: Literature review and trends. Journal of Industrial Engineering and Management, 12(2), 302-317. https://doi.org/10.3926/jiem.2885 


\section{Introduction}

Companies today are constantly in search of solutions to meet the challenges of competition, marketplace and the institutional environment that they exist in order to move up the ladder in the dynamic market scenario. Lean production has emerged as one of the most significant Operations Management paradigm at the behest of organizations to meet dual objectives of improving quality, flexibility and delivery while at the same time focusing on cost reduction (Krafcik, 1988; Slack, Lewis \& Bates, 2004; Pilkington \& Fitzgerald, 2006; Hasle, Bojesen, Langaa-Jensen \& Bramming, 2012; Jasti \& Kodali, 2014). Lean phenomenon has its origin in Japan but it has assumed worldwide adoption. The global manufacturing landscape has drastically shifted with emerging economies gaining ascent. This has led to increased application of lean methodologies by organizations to remain competitive, meet customers need and optimize operations (Ghosh, 2012; Chaplin, Heap, \& O'Rourke, 2016). There has also been a remarkably increased academic interest in the field of lean in the past few decades (Negrão, Godinho-Filho \& Marodin, 2017). The term 'Lean' was coined by John Krafcik in an article in MIT Sloan Management Review, but the term became popular as a result of the publication of the book 'The Machine That Changed The World', which was a result of five year IMVP (International Motor Vehicle Program) study conducted at MIT which pointed out the performance gap between Japan and western automotive sector. The book had direct implications for managers and practitioners all over the world and led to widespread adoption of lean across manufacturing and services sector. Lean has evolved into an inter-disciplinary subject with linkages to Operations Management, Organizational Behavior, Strategic Management (Forza, 1996; Emiliani, 1998; Atkinson, 2010; Bamber, Stanton, Bartram \& Ballardie, 2014; Bhasin, 2015; Hallam \& Contreras, 2016.)

Lean has been defined in numerous ways highlighting its numerous facets. Table 1 lists key aspects of lean definition as identified by authors.

\begin{tabular}{|l|l|}
\hline Author & Lean manufacturing definition \\
\hline Krafcik (1988) & $\begin{array}{l}\text { Using less of organizational resources as compared to resources deployed in mass } \\
\text { production. }\end{array}$ \\
\hline Womack, Jones and Roos (1990) & $\begin{array}{l}\text { Fusion of mass and craft production consisting of set of principles and best practices } \\
\text { aiming at continuous improvement }\end{array}$ \\
\hline Shah and Ward (2003) & $\begin{array}{l}\text { Lean is an integrated system consisting of inter-related elements and management } \\
\text { practices aimed at delivering value to customers. }\end{array}$ \\
\hline Shah and Ward (2007) & $\begin{array}{l}\text { Lean production defined as socio-technical system with focus on elimination of waste } \\
\text { throughout the organization as well as its supply chain network. }\end{array}$ \\
\hline
\end{tabular}

Table 1. Lean Manufacturing Definitions: Key Aspects

Many authors have embarked on the mission to define lean as a bundle of techniques to reduce waste; as a management philosophy; or as a socio -technical system to deliver value to customers (Bicheno, 2004; Hines, Holweg \& Rich, 2004; Bhasin \& Burcher, 2006; Shah \& Ward, 2007; Taj \& Morosan, 2011). The inconclusiveness in defining lean reflects the expansion of lean over a period of time as well as its configural nature (De Treville \& Antonakis, 2006; Tiamaz \& Souissi, 2019). Amelioration to better understand lean continues.

A retrospection of the extant literature would facilitate understanding of lean diffusion globally along with analysis of sectoral patterns and trends found in the published literature. The aim of the paper is to comprehensively review the existing lean manufacturing literature with the purpose of succinct representation of the current status and facilitating future research in the field. The key objectives of this paper are:

- To study the evolution of lean over a period of time

- To study diffusion of lean (geographic spread) in general as well as in the context of emerging economy

- To identify themes that have emerged over a period of time

- To identify research gaps and future direction that exists in literature 


\section{Review of Literature}

Mulrow (1994) suggests that literature review is search for whole truth, rather than just part of it, and therefore is a 'fundamentally scientific activity'. During the last 3 decades, lean research has reached a level of maturity. To take a stock of knowledge accumulated in these three decades, comprehensive literature survey has been adopted as the research methodology. It has been successfully applied in analysing research on other manufacturing systems such as Total Quality Management (Ahire, Landeros \& Golhar, 1995), Six Sigma (Brady \& Allen, 2006), Just-in-time philosophy (Golhar \& Stamm, 1991) as well.

Narayanamurthy and Gurumurthy (2016) reviewed literature on lean assessment to understand its evolution. The Article by Samuel, Found \& Williams, 2015, attempted to cover the progression of lean from its origin as a representation of Toyota Production System to a movement that has changed management systems in diverse sectors. Jasti and Kodali (2014) in their article conducted an extensive review of empirical research in lean. The extensive research though insightful is limited to empirical research in 178 articles in 24 journals. Another article by Jasti and Kodali (2015b) performed analysis of literature from 1988 to 2011. Bhamu and Singh-Sangwan (2014) reviewed 209 research papers with the purpose of reporting diverse definitions, scopes, objectives and tools. Stone (2012) conducted systematic literature review to thematically organize lean literature till 2009 into phases. Negrão et al., 2017 conducted review of literature of 83 studies with a view to provide an understanding of the degree of adoption of lean and its relationship with organizational performance. Hu, Mason, Williams and Found (2015) reviewed literature pertaining to implementation of lean in SMEs. Hines et al. (2004) reviewed lean thinking and its progression over time identifying four key stages in its development. Holweg (2007) and Moyano-Fuentes and Sacristan-Díaz (2012) focussed on aspects on lean production. The present study extends efforts of previous studies by including contemporary research till 2017 providing an overview of developments that have taken place in the field of lean management over past three decades. The study aim to analyse diffusion of lean globally, specifically in the context of emerging economies, which is considered prudent considering rising popularity of lean as an operational model as well as identifying prevalent themes along with the new themes that have emerged such as Industry 4.0 which have not been addressed in earlier works.

\section{Methodology}

This paper attempts to highlight the importance and evolution of lean methodology through a comprehensive literature review. Gamal-Aboelmaged (2010) reiterates the use of journal to obtain and publish research findings. Therefore this study includes studies published in journal that add to existing body of knowledge and application. It was decided to include articles from three major academic sources namely: Emerald Insight, Taylor \& Francis and Science Direct. Following criteria was used in each of the databases:

- Emerald - suitable journals were selected using the subject criteria. In the selected journals, articles were searched with 'lean' in title.

- T\&F - 'lean' was searched in title to select relevant articles.

- ScienceDirect - search was conducted with 'lean' in title and management in subject to exclude papers not from the field

To exclude articles that are not relevant and further narrow down the number of articles, following filters were used as well:

- Only those articles were included where lean is mentioned in the title of paper, the idea was to include articles with the main theme as lean which deal with lean concept in a non-trivial and non-marginal way.

- Lean six sigma, which is an evolution of lean and six sigma, has been excluded from the study. Papers specifically focussing on one of the lean techniques i.e. JIT, Kaizen etc. have also been excluded.

- Only the term 'Lean' was used as opposed to previous literature reviews in which selected few terms amongst the various terms used to describe lean such as lean production, lean manufacturing, lean philosophy, Toyota Production system, lean thinking, lean management, lean techniques etc. were used to make the study more exhaustive. 
A database of articles included in the paper was created in excel including attributes: Year, publisher, study type, industry, country, theme in order to conduct trend analysis of the existing body of knowledge and draw meaningful conclusions. The earliest article available online is in 1994 while the latest article pertains to September 2017. One serious limitation while conducting the research work was the access available to researcher. Only those articles with full access have been included in the research. The final list consists of 51 journals and 447 articles as reflected in Table 2.

Articles were screened for chronological evolution, geographic spread where research has been conducted with special focus on emerging economies and themes that could be identified from the existing literature. Findings are discussed in the following sections.

\begin{tabular}{|l|r|}
\hline \multicolumn{1}{|c|}{ Publisher } & Number of Research Articles \\
\hline Emerald Insight & 191 \\
\hline Taylor \& Francis & 173 \\
\hline ScienceDirect & 83 \\
\hline Total & 447 \\
\hline
\end{tabular}

Table 2. Research articles details by publisher

\section{Findings}

A glance at the Table 3 reflects that lean as a subject has been studied with great interest in operations management literature as can be seen from large number of articles in well reputed OM journal. International Journal of Production Research itself accounts for $15 \%$ of the articles considered in the study. The list of 17 journals given below in Table 3 approximately accounts for $82 \%$ of the articles. The high concentration of articles on lean management in these journals reflects on its wider application in operations and production stream, although it was observed from the complete list of 51 journals that linkages to various other management areas can also be seen through titles of the journals such as the field of education, human resource management, behavioural sciences, construction and services.

\begin{tabular}{|c|l|r|}
\hline S. No. & \multicolumn{1}{|c|}{ Journal } & Number of Articles \\
\hline 1 & International Journal of Production Research & 68 \\
\hline 2 & International Journal of Operations \& Production Management & 50 \\
\hline 3 & Journal of Manufacturing Technology Management & 46 \\
\hline 4 & Production Planning \& Control & 35 \\
\hline 5 & International Journal of Production Economics & 20 \\
\hline 6 & International Journal of Lean Six Sigma & 18 \\
\hline 7 & Total Quality Management \& Business Excellence & 17 \\
\hline 8 & Procedia Engineering & 15 \\
\hline 9 & Procedia Manufacturing & 15 \\
\hline 10 & International Journal of Productivity and Performance Management & 15 \\
\hline 11 & Benchmarking: An International Journal & 14 \\
\hline 12 & Journal of Operations Management & 13 \\
\hline 13 & Assembly Automation & 10 \\
\hline 14 & International Journal of Computer Integrated Manufacturing & 8 \\
\hline 15 & The TQM Journal & 8 \\
\hline 16 & International Journal of Quality \& Reliability Management & 8 \\
\hline 17 & Journal of Manufacturing Systems & 8 \\
\hline & Total & 368 \\
\hline
\end{tabular}

Table 3. Research article in Journals 


\subsection{Year Wise Distribution of Lean Publication}

There has been a remarkable surge in the number of research papers over the years. The interest in lean has peaked to a great extent since 2010. Three distinct phases can be observed in the trajectory of lean evolution through number of publications on this theme. As observed in Figure 1, lean publication has almost increased by almost more than 3 times in each Time period. There has been a jump from 35 to 320 from 1994-2000 to 2011-2017. This suggests increased acceptance of lean as an improvement intervention in academia as well as industry. One of the reasons for heightened interest is global recession which forced organizations to reduce costs (Bhamu \& Singh-Sangwan, 2014). Another reason is acceptance of lean as an operational model to combat competition and attempt of developing countries like China and India to move up the value chain (Panizzolo, Garengo, Sharma \& Gore, 2012).

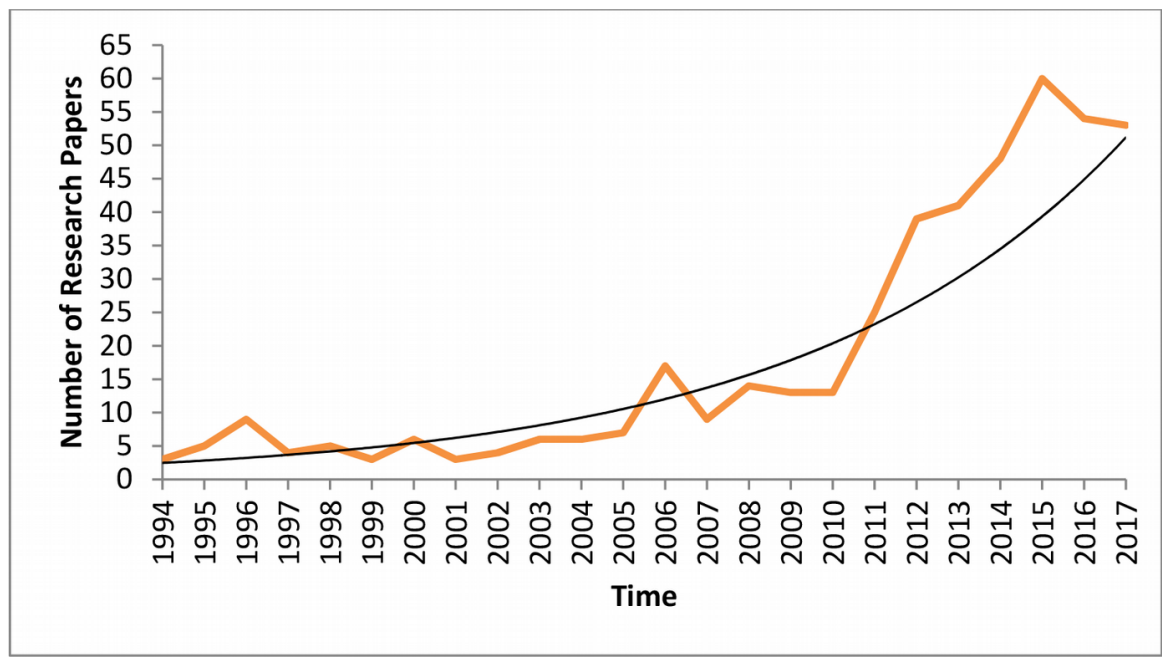

Figure 1. Lean publications over the years

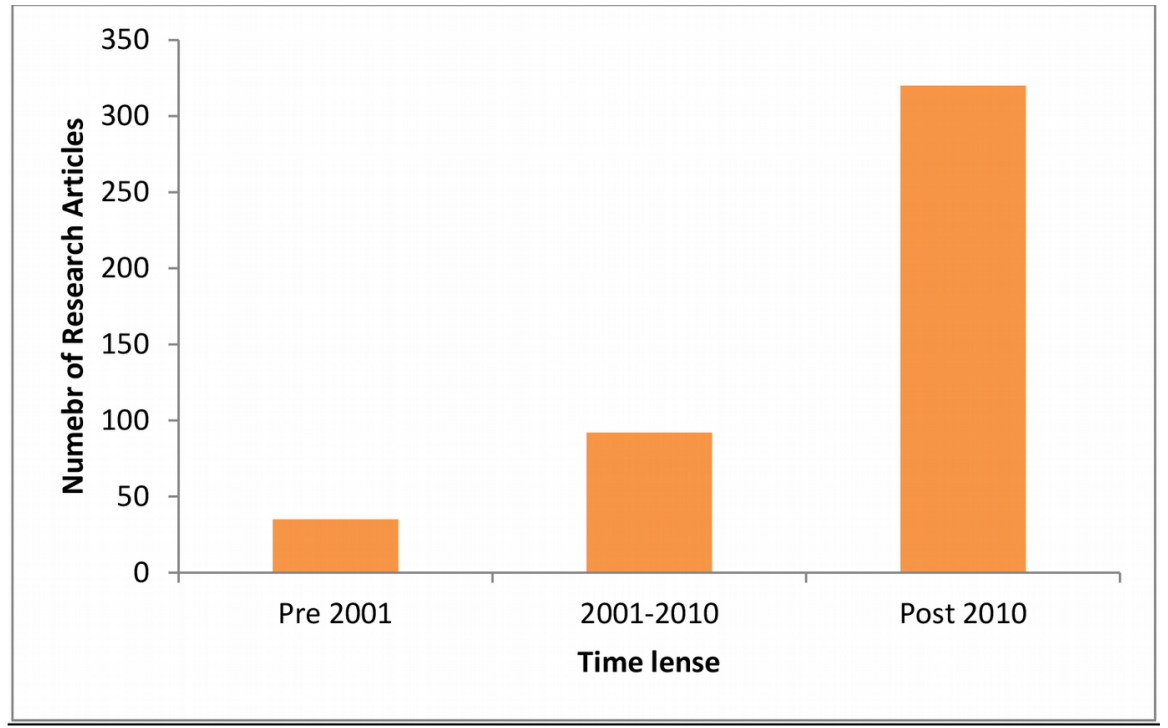

Figure 2. Lean publication through Time Lense

The huge rise in the number of research paper in each phase warrants study of reviewed articles by analyzing them through three-time lenses Pre 2001, 2001-2010, Post 2010 as seen in Figure 2. It would help in drawing some notable conclusions about the maturity of the subject, trends and themes. 


\subsection{Time Periods}

\subsubsection{Pre -2001}

The first published article in the reviewed database appears in 1994, about 4 years after study at MIT which led to the publication of the book 'The machine that changed the world'. 35 research articles could be found in this time period.

During the initial phase developed counties spearheaded adoption of lean. In this time period only 1 case study was reported from China. As per the sectoral pattern, of the 35 studies, most have been conducted in manufacturing sector which included auto - component, aerospace, shipbuilding etc. with none from services. In the initial years, lean management was considered mostly applicable to manufacturing industry. Another significant observation is that around $57 \%$ studies that have been conducted till 2000 were case study based. This could be due to soundness of case study method for exploration and theory building at early stages of programme (Voss \& Tsikriktsis, 2002).

\subsubsection{1-2010}

Number of research papers reviewed during 2001-2010 are 92. The bulk of the research i.e. $43.4 \%$ pertains to 2008 onwards, the reason for this could be realization of cost reduction potential of lean during this time period. Lean management came to the rescue of the global industry as the world saw one of the worst recessions following the year 2007, forcing organizations to embark on cost reduction strategies. This period also witnessed growth in survey research method with 19 papers using it as a research method, although case study still seemed to be the most popular method. The number of studies conducted in service industry in this phase is small yet a beginning is made. An increased number of articles during this period discussed enhancement of lean concept beyond production system. This indicated recognition of lean as a management philosophy with a much broader application than perceived before (Hines et al., 2004; Bhasin \& Burcher, 2006; Petterson, 2009).

\subsubsection{Post 2010}

The interest in lean has gained momentum over the past few years tremendously (Marodin \& Saurin, 2013; Jasti \& Kodali, 2015b). The numbers of article in the past 7 years have increased manifold from 92 to 320 . The economic downturn spurred the interest in lean which is visible in this time period. With global competition at its peak and rising production costs, companies have been forced to look at new operational strategy. Lean benefits like lead time reduction, cost savings, reduction in wastes motivates organizations to embark on green and sustainable solutions.

A look at the top 5 countries with highest number of lean studies (Table 4) shows the tilt towards developing economies. Maximum numbers of studies, as opposed to previous decades, have been from emerging economies with India in the forefront with as many as 36 studies.

Lean has been approached using different research methodologies. Case study is still preferred method although the number of studies using survey based method has increased in this time frame (as many as 91). Looking at the sectoral spread, lean has ingressed into various fields which displays its versatility. Apart from Automotive sector, electronics and other manufacturing industries studies have been conducted in diverse sectors such as healthcare, public service, pharmaceutical, education etc.

\begin{tabular}{|c|r|}
\hline Country & Number of Research Articles \\
\hline India & 36 \\
\hline UK & 27 \\
\hline Brazil & 18 \\
\hline US & 16 \\
\hline Malaysia & 8 \\
\hline
\end{tabular}

Table 4. Countries with highest number of Studies in lean 


\subsection{Country Classification}

Whereas studies conducted in developed countries are definitely more (Table 5), but the research in developing countries are catching up to bridge the gap as can be seen from the gap between the lines mapping spread of lean in developed and developing nations respectively is reducing over a period of time in Figure 3.

\begin{tabular}{|l|r|r|r|r|}
\hline & Pre 2001 & 2001 -2010 & Post 2010 & Grand Total \\
\hline Developed countries & 18 & 40 & 105 & 163 \\
\hline Developing countries & 1 & 14 & 99 & 114 \\
\hline -NA- & 16 & 38 & 116 & 170 \\
\hline Grand Total & 35 & 92 & 320 & 447 \\
\hline
\end{tabular}

Table 5. Country Classification of Lean Studies

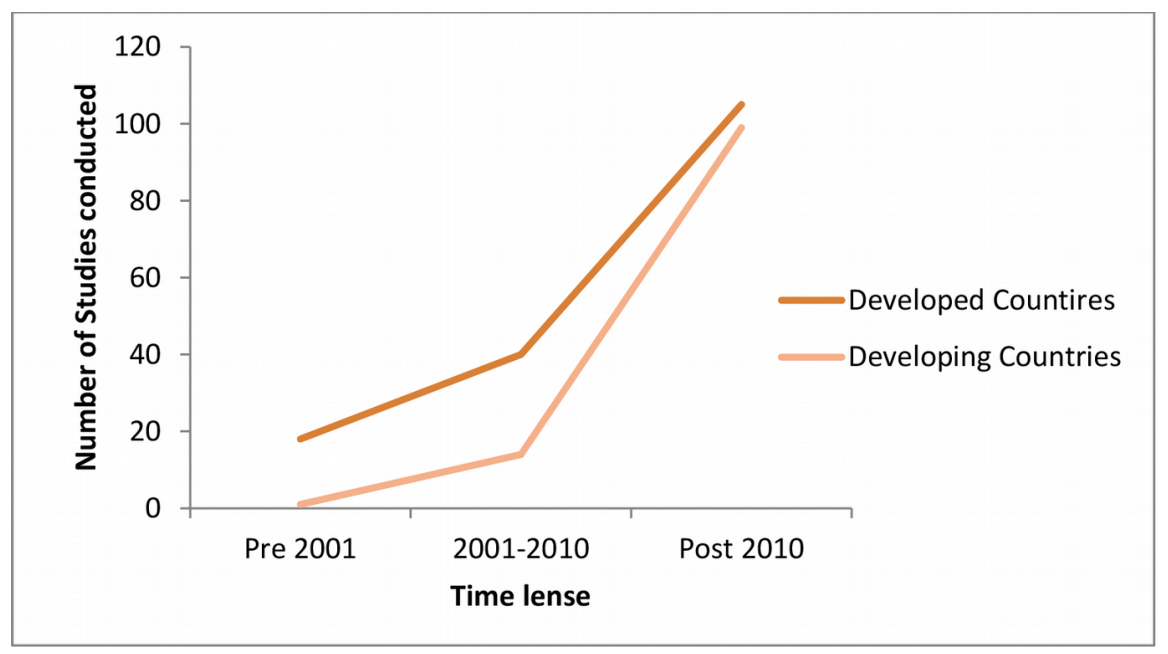

Figure 3. Lean publication: Developed Countries vs. Developing Countries

According to research papers considered in this study lean studies have been conducted in 45 countries approximately, which reflects high level of dispersion and its universal application. Despite its origin in Japan, lean has found its way in all parts of the world. Table 6 brings to light spread of lean throughout the world. Manufacturing approaches like lean have established itself as a powerful tool to face global Competition.

Just as manufacturing and industrial technology adoption was transferred from developed to developing economies, lean has also followed similar path. The book 'The Machine that changed the World' acted as an eye opener for other TRIAD countries. Developed nations quickly learnt from Japanese experience and started adopting it. It is only since the beginning of 21 st century, as the share of manufacturing of developing nations improved, with Asian economies in the forefront, that lean gained popularity as process improvement methodology (Szirmai, 2009).

\subsection{Lean Evolution in context of Emerging Economies}

Lean has its roots in the automotive sector; hence its evolution can be traced back to developments that have occurred in the automobile industry. The automobile industry was recognized as the 'the industry of industries' in the twentieth century and is considered one of the most globalised industries (Jain \& Garg, 2007). 'The Machine That Changed The World' provided an account of the history of automobile manufacturing combined with a comparative study of Japanese, American, and European automotive assembly plants which highlighted the performance gap between Toyota and others (Hines et al., 2004). This study brought lean into the limelight and led to spill over effect to the North American and European manufacturers causing them to rethink their methods in 
line with the Japanese practices. (Helper \& Sako, 1995; Wasti \& Liker, 1999; Mejza, Laosirihongthong \& Prajogo, 2013).

\begin{tabular}{|c|c|c|c|c|}
\hline Europe & Africa & Asia & Other Countries & Americas \\
\hline Belgium & Egypt & China & Australia & North America \\
\hline Denmark & Libya & India & New Zealand & Canada \\
\hline Finland & South Africa & Indonesia & & US \\
\hline France & & Iraq & & South America \\
\hline Netherland & & Malaysia & & Ecuazil \\
\hline Luxembourg & & Pakistan & & Columbia \\
\hline Germany & & South Korea & & Central America \\
\hline Greece & & Sri Lanka & & Latin America \\
\hline Hungary & & Taiwan & & Trinidad and Tobago \\
\hline Ireland & & Thailand & & \\
\hline Italy & & Dubai & & \\
\hline Norway & & Iran & & \\
\hline Portugal & & Japan & & \\
\hline Spain & & Turkey & & \\
\hline Sweden & & & & \\
\hline UK & & & & \\
\hline Lithuania & & & & \\
\hline Norway & & & & \\
\hline Poland & & & & \\
\hline
\end{tabular}

Table 6. Regional distribution of Lean publication

Japan being part of Asia integrated its automotive supply chain with other Asian countries like Thailand, Taiwan, and other ASEAN countries etc. and paved the way for implementation of lean in these regions (Farrell \& Findlay, 2001). The remarkable market expansion in these emerging economies prompted by sustained economic growth and radical changes in policies in India and China also supported lean efforts (Mukherjee \& Sastry, 1996).

TRIAD market which included North America, Western Europe and Japan have gone through decline in their importance with simultaneous steady rise of the emerging economies (Fan, 2008; Marinov \& Marinova, 2012). Thornton (2010) opines that the manufacturing sector is in different phases of transformation. Developed nations are applying lean in unconventional areas and becoming productive. The manufacturers in emerging economies are in the growth phase. They not only competing on cost but also trying to move up the value chain. These countries with export led growth strategy have adopted lean management to meet the quality standards of the developed economies.

The emerging economies like Brazil, Mexico, India and China are inherently different from each other but they share commonalities to quite an extent (Bollbach, 2012). They were protected domestic markets but globalization introduced them to competition from international companies. The shift to competitive buyers' market has made emerging economies focus on quality and efficient production. These economies aim to increase exports by improving production parameters such as quality, cost, delivery and flexibility. The scenario has led to lean management gaining its popularity as a successful intervention to achieve competitive advantage, which is reverberated in the notable increase in the studies conducted in these countries. 


\subsection{Research Themes}

A review of prior research in lean management is important for undertaking any future research project in the field and to take cognizance of the work done so far which provides a firm foundation to proceed further in the field of research. Vast amount of literature on lean exists but there is a lack of convergence. This paper attempts to classify research articles on the basis of themes. It also aims to help researchers explore new avenues for theory building and validation.

The most dominant theme found in literature is lean adoption. Considering the conundrum regarding lean implementation, this observation is not surprising. Some of the significant barriers to lean implementation includes; lack of top management support, ineffective communication resulting into inadequate dissemination of the lean benefits. This is followed by lean and its impact on performance. It has been reported that corporate organizations experience reduction of lead time and inventory levels, yet there is further scope for achievement of better operational performance results. Organizational theory and lean is also a common theme but there seems to be lack of consolidation. Contemporary themes include sustainability and green practices, compatibility of Lean with other improvement tools and synergies between Industry 4.0 and lean. In the context of Industry 4.0 and lean, it needs to be seen how effectively lean techniques can be combined with automation technology embedded in Industry 4.0.

\begin{tabular}{|c|c|}
\hline Classification & Details \\
\hline Lean Adoption & $\begin{array}{l}\text { Includes factors impacting lean implementation; barriers or issues faced while adopting lean; lean } \\
\text { product development etc.; implementation and application in various industries such as healthcare, } \\
\text { education etc. (Nordin, Deros \& Wahab, 2011; Bhasin, 2012; Sisson \& Elshennawy, 2015; } \\
\text { Abolhassani, Layfield \& Gopalakrishnan, 2016; Tortorella, Marodin, Fettermann \& Fogliatto, 2016; } \\
\text { Narayanamurthy, Gurumurthy \& Chockalingam, 2017; Satolo, Hiraga, Goes \& Lourenzani, 2017) }\end{array}$ \\
\hline Lean Performance & $\begin{array}{l}\text { Includes impact of lean on organizational performance including operational performance, } \\
\text { financial performance etc. (Bhasin, 2008; Fullerton \& Wempe, 2009; Belekoukias, Garza-Reyes \& } \\
\text { Kumar, 2014; Uhrin, Bruque-Camara \& Moyano-Fuentes, 2017; Negrão et al., 2017) }\end{array}$ \\
\hline Leanness & $\begin{array}{l}\text { Includes research papers that discuss leanness assessment or measurement (Papadopoulou \& } \\
\text { Özbayrak, 2005; Singh, Garg \& Sharma, 2010; Vinodh \& Kumar-Chintha, 2011; Ram-Matawale, } \\
\text { Datta \& Sankar-Mahapatra, 2014) }\end{array}$ \\
\hline Lean supply Chain & $\begin{array}{l}\text { Includes papers that discuss adoption of lean principles, concepts, tools and techniques } \\
\text { throughout the entire supply chain aimed at elimination of waste and non-value-added activities } \\
\text { from the overall value stream in the supply chain (Stentoft-Arlbjørn, Vagn-Freytag \& de Haas, } \\
\text { 2011; Ma, Wang \& Xu, 2011; Jasti \& Kodali, 2015a; Tortorella, Miorando \& Tlapa, 2017) }\end{array}$ \\
\hline $\begin{array}{l}\text { Lean and other value } \\
\text { creation tools }\end{array}$ & $\begin{array}{l}\text { Includes papers which discuss lean and other process improvement methodologies like TQM, Six } \\
\text { sigma, Agile (Dahlgaard \& Dahlgaard-Park, 2006; Naslund, 2008; De Koeijer, Paauwe \& } \\
\text { Huijsman, 2014; Mehrsai, Thoben \& Scholz-Reiter, 2014) }\end{array}$ \\
\hline Lean Epistemology & $\begin{array}{l}\text { Includes research articles that deliberate on its conceptual issues, methods, validity and scope } \\
\text { (Bhasin \& Burcher, 2006; Found \& Rich, 2007; Petterson, 2009; Saurin, Rooke \& Koskela, 2013; } \\
\text { Langstrand \& Drotz, 2016) }\end{array}$ \\
\hline $\begin{array}{l}\text { Organizational Theory } \\
\text { and Lean }\end{array}$ & $\begin{array}{l}\text { Includes papers examining relationship between Human resource management, Culture, } \\
\text { Management support, leadership and lean (Forrester, 1995; Conti, Angelis, Cooper, Faragher \& } \\
\text { Gill, 2006; Bamber et al., 2014; Pakdil \& Leonard, 2015; Worley \& Doolen, 2015; Tortorella, } \\
\text { Marodin, Fogliatto \& Miorando, 2015) }\end{array}$ \\
\hline Lean and sustainability & $\begin{array}{l}\text { Includes research articles that discuss relationship between lean and sustainability and green } \\
\text { practices (Alves \& Alves, 2015; Longoni \& Cagliano, 2015; Piercy \& Rich, 2015; Hallam \& } \\
\text { Contreras, 2016; Raj, Ma, Gam \& Banning, 2017) }\end{array}$ \\
\hline Industry 4.0 and Lean & $\begin{array}{l}\text { (Mrugalska \& Wyrwicka, 2017; Kolberg, Knobloch \& Zühlke, 2017; Tortorella \& Fettermann, } \\
\text { 2018) }\end{array}$ \\
\hline
\end{tabular}

Table 7. Lean Research Themes 


\section{Discussion and Implications}

This article makes several contributions to the field of operations management literature. First, by using well established methodology, the article updates earlier literature reviews and provides insight into trends and advancement in the field. Secondly, the article traces lean studies in various geographical regions with special mention of its adoption in emerging economies to accelerate their development. It has been observed that very few studies discuss contextual factors while implementing lean in emerging economies, which becomes even more significant due to interplay of economic factors, government policies, human capital and civil infrastructure factors. There is also an opportunity for emerging economies to significantly impact their pace of development by exploring new avenues such as integration of sustainability practices along with lean, pursuing lean in combination with other improvement methodologies such as six sigma, agility and TQM.

Thirdly, undertaking of reflective perusal of lean studies suggests common themes found in literature. Bulk of studies discuss experiences, adoptions and implementation extending beyond shop- floor of manufacturing units to services, education, healthcare etc. Application of lean to entire supply chain and other areas such as product development has also been widely examined. Another common theme found among studies deal with nature of lean concept, which is simple to understand but complex to implement. Another subject that is gaining interest is potential benefits of amalgamation of Industry 4.0 and lean in manufacturing. Research reflects substantial advancement in the field of lean management. The journey from being tools limited to shop - floors activities to operations strategy holds lessons for managers, practitioners as well as academicians.

Various researches have operationalized Lean Management. Despite various attempts there is an ambiguity in defining lean even after decades of research which has contributed to mixed results. Key factors impacting lean implementation that have found recurring mention in the literature are managers' sustained commitment, organizational culture, lack of resources and workers' involvement. The link between organizational behaviour and lean as improvement methodology is deep rooted and finds frequent mention in literature yet research in this area is fragmented. Social and organizational dimension of lean is an ongoing debate in academia. (Priyono \& Idris, 2018; Gao \& Gurd, 2019; Laureani \& Anotony, 2019; Secchi \& Camuffo, 2019; Yadav, Jain, Mittal, Panwar \& Sharma, 2019). This serves as an opportunity for academicians to conduct research in developing soft lean practice related to principles, people and relations that support lean tools and techniques which would lead to sustained positive results.

Lean adoption studies provide insight to practitioners about the enablers and inhibitors while implementing lean. This awareness can facilitate more effective lean adoption leading to fewer failures and also set realistic expectations regarding results to be attained through lean intervention. For instance, behavioral change must preempt lean intervention in any organization where lean is perceived by all organization members as an aid to making their work more effective. Similarly, diagnosing existing organizational culture and adopting lean tools and techniques accordingly would also be advisable. Extension of lean beyond the organization to entire supply chain as an operational strategy offers a powerful tool at the behest of the managers to combat competition. Evidence of successful application in service sectors such as education and healthcare would convince practitioners of universality of lean as a Performance Improvement methodology and extend its adoption to other sectors as well. Managers and practitioners can benefit from the complementary nature of lean with other performance improvement methodology such as Six Sigma, agility and TQM. Such an approach would reduce drain on resources in case they are implemented in isolation. The focus of any improvement program must extend to include environmental benefits. Integration of sustainability issues with lean management holds promise as lean promotes use of fewer resources. Embracing environmental sustainability practices along with lean production would be beneficial for managers as they will be able to meet goal of being competitive while being socially responsible.

\section{Conclusion and Future Direction}

Popularity of lean in operations management is evident from the number of publications in the field. Lean production has taken center stage in operations management research $(\mathrm{OM})$ in the last decades (Holweg, 2007; Negrão, et al., 2017). Systematic review of literature indicates that the most dominant theme found in literature is 
lean adoption, followed by lean and its relation to performance. Lean is also emerging as an important dimension in organizational theory literature but there is a need for further consolidation. Compatibility of lean with sustainability and green practices is also reflected in the contemporary literature. The superiority of lean as process improvement methodology led to conformance by the manufacturers globally to the paradigm. The present business environment with its rapid changes in market, rise in its economic, technical, and socio-psychological complexities has paved way for acceptance of lean as an operating strategy in a pervasive manner. As suggested by Duncan and Ritter (2014), the wider application of lean has led to better appreciation of the power of its underlying management principles: putting customer needs first, understanding their needs and delivering it with efficiency, value chain optimization and drive to continuous improvement in operations.

Future studies can focus on developing framework that integrates soft lean practices with hard lean tools and techniques that would pave way for transformation of enterprise. With the introduction of Industry 4.0 along with Internet of things, information and communications technology (ICT), there is an opportunity to re-invent lean to suit current industry requirements. Combining Industry 4.0 with Lean management would help to harness benefits of automation and IT integration of production, planning, suppliers and customers which would lead to greater flexibility and efficiency in manufacturing.

\section{Declaration of Conflicting Interests}

The authors declared no potential conflicts of interest with respect to the research, authorship, and/or publication of this article.

\section{Funding}

The authors received no financial support for the research, authorship, and/or publication of this article.

\section{References}

Abolhassani, A., Layfield, K., \& Gopalakrishnan, B. (2016). Lean and US manufacturing industry: popularity of practices and implementation barriers. International Journal of Productivity and Performance Management, 65(7), 875-897. https://doi.org/10.1108/IJPPM-10-2014-0157

Ahire, S.L., Landeros, R., \& Golhar, D.Y. (1995). Total quality management: A literature review and an agenda for future research. Production and Operations Management, 4(3), 277-306. https://doi.org/10.1111/j.1937-

5956.1995.tb00057.x

Alves, J.R.X., \& Alves, J.M. (2015). Production management model integrating the principles of lean manufacturing and sustainability supported by the cultural transformation of a company. International Journal of Production Research, 53(17), 5320-5333. https://doi.org/10.1080/00207543.2015.1033032

Atkinson, P. (2010). Lean is a cultural issue. Management Services, 54(2), 35-41.

Bamber, G.J., Stanton, P., Bartram, T., \& Ballardie, R. (2014). Human resource management, Lean processes and outcomes for employees: towards a research agenda. The International Journal of Human Resource Management, 25(21), 2881-2891. https://doi.org/10.1080/09585192.2014.962563

Belekoukias, I., Garza-Reyes, J.A., \& Kumar, V. (2014). The impact of lean methods and tools on the operational performance of manufacturing organisations. International Journal of Production Research, 52(18), 5346-5366. https://doi.org/10.1080/00207543.2014.903348

Bhamu, J., \& Singh-Sangwan, K. (2014). Lean manufacturing: literature review and research issues. International Journal of Operations \& Production Management, 34(7), 876-940. https://doi.org/10.1108/IJOPM-08-2012-0315

Bhasin, S., \& Burcher, P. (2006). Lean viewed as a philosophy. Journal of manufacturing technology management, 17(1), 56-72. https://doi.org/10.1108/17410380610639506

Bhasin, S. (2008). Lean and performance measurement. Journal of Manufacturing Technology Management, 19(5), 670684. https://doi.org/10.1108/17410380810877311 
Bhasin, S. (2012). Prominent obstacles to lean. International Journal of Productivity and Performance Management, 61(4), 403-425. https://doi.org/10.1108/17410401211212661

Bhasin, S. (2015). Lean management beyond manufacturing. New York, NY: Springer. https://doi.org/10.1007/978-3-31917410-5

Bicheno, J. (2004). The new lean toolbox: towards fast, flexible flow. Production and Inventory Control, Systems and Industrial Books (PICSIE Books).

Bollbach, M. (2012). Country-specific barriers to implementing lean production systems in China. Doctoral dissertation, Marc Fabian Bollbach.

Brady, J.E., \& Allen, T.T. (2006). Six Sigma literature: a review and agenda for future research. Quality and reliability engineering International, 22(3), 335-367. https:// doi.org/10.1002/qre.769

Chaplin, L., Heap, J., \& O’Rourke, S. T. (2016). Could "Lean Lite” be the cost effective solution to applying lean manufacturing in developing economies?. International Journal of Productivity and Performance Management, 65(1), 126-136. https://doi.org/10.1108/IJPPM-02-2015-0034

Conti, R., Angelis, J., Cooper, C., Faragher, B., \& Gill, C. (2006). The effects of lean production on worker job stress. International journal of operations \& production management, 26(9), 1013-1038.

https://doi.org/10.1108/01443570610682616

Dahlgaard, J.J., \& Mi Dahlgaard-Park, S. (2006). Lean production, six sigma quality, TQM and company culture. The TQM magazine, 18(3), 263-281. https://doi.org/10.1108/09544780610659998

De Koeijer, R.J., Paauwe, J., \& Huijsman, R. (2014). Toward a conceptual framework for exploring multilevel relationships between Lean Management and Six Sigma, enabling HRM, strategic climate and outcomes in healthcare. The International Journal of Human Resource Management, 25(21), 2911-2925. https://doi.org/10.1080/09585192.2014.953974

De Treville, S., \& Antonakis, J. (2006). Could lean production job design be intrinsically motivating? Contextual, configurational, and levels-of-analysis issues. Journal of Operations Management, 24(2), 99-123.

https://doi.org/10.1016/j.jom.2005.04.001

Duncan, E., \& Ritter, R. (2014). Next frontiers for lean. McKinsey Quarterly, 2, 82-89.

Emiliani, M.L. (1998).Lean behaviours. Management Decision, 36(9), 615-631. https://doi.org/10.1108/00251749810239504

Fan, Y. (2008). The rise of emerging market multinationals and the impact on marketing. Marketing Intelligence \& Planning, 26(4), 353-358. https://doi.org/10.1108/02634500810879269

Farrell, R., \& Findlay, C. (2001). Japan and the ASEAN4 automotive industry: Developments and inter-relationships in the regional automotive industry. Kitakyushu: International Centre for the Study of East Asian Development (ICSEAD), 2001-24, 1-116.

Forrester, R. (1995). Implications of lean manufacturing for human resource strategy. Work. Study, 44(3), 20-24. https://doi.org/10.1108/00438029510146944

Found, P., \& Rich, N. (2007). The meaning of lean: cross case perceptions of packaging businesses in the UK's fast moving consumer goods sector. International Journal of Logistics research and applications, 10(3), 157-171. https://doi.org/10.1080/13675560701463812

Forza, C. (1996). Work organization in lean production and traditional plants: what are the differences?. International Journal of Operations \& Production Management, 16(2), 42-62. https://doi.org/10.1108/01443579610109839

Fullerton, R.R., \& Wempe, W.F. (2009). Lean manufacturing, non-financial performance measures, and financial performance. International Journal of Operations \& Production Management, 29(3), 214-240. https://doi.org/10.1108/01443570910938970

Gamal-Aboelmaged, M. (2010). Six Sigma quality: a structured review and implications for future research. International Journal of Quality \& Reliability Management, 27(3), 268-317. https://doi.org/10.1108/02656711011023294 
Gao, T., \& Gurd, B. (2019). Organizational issues for the lean success in China: exploring a change strategy for lean success. BMC health services research, 19(1), 66. https://doi.org/10.1186/s12913-019-3907-6

Ghosh, M. (2012). Lean manufacturing performance in Indian manufacturing plants. Journal of Manufacturing Technology Management, 24(1), 113-122. https://doi.org/10.1108/17410381311287517

Golhar, D.Y., \& Stamm, C.L. (1991). The just-in-time philosophy: a literature review. The International Journal of Production Research, 29(4), 657-676. https:/ / doi.org/10.1080/00207549108930094

Hallam, C., \& Contreras, C. (2016). Integrating lean and green management. Management Decision, 54(9), $2157-2187$. https://doi.org/10.1108/MD-04-2016-0259

Hasle, P., Bojesen, A., Langaa-Jensen, P., \& Bramming, P. (2012). Lean and the working environment: a review of the literature. International Journal of Operations \& Production Management, 32(7), 829-849.

https://doi.org/10.1108/01443571211250103

Helper, S.R., \& Sako, M. (1995). Supplier relations in Japan and the United States: are they converging?. Sloan Management Review, 36(3), 77-85.

Hines, P., Holweg, M., \& Rich, N. (2004). Learning to evolve: a review of contemporary lean thinking. International journal of operations \& production management, 24(10), 994-1011. https://doi.org/10.1108/01443570410558049

Holweg, M. (2007). The genealogy of lean production. Journal of operations management, 25(2), 420-437. https://doi.org/10.1016/j.jom.2006.04.001

Hu, Q., Mason, R., Williams, S.J., \& Found, P. (2015). Lean implementation within SMEs: a literature review. Journal of Manufacturing Technology Management, 26(7), 980-1012. https://doi.org/10.1108/JMTM-02-2014-0013

Jain, S., \& Garg, R.K. (2007). Business competitiveness: strategies for automobile industry. Doctoral dissertation, Indian Institute of Management Kozhikode.

Jasti, N.V.K., \& Kodali, R. (2015a). A critical review of lean supply chain management frameworks: proposed framework. Production Planning \& Control, 26(13), 1051-1068. https://doi.org/10.1080/09537287.2015.1004563

Jasti, N.V.K., \& Kodali, R. (2015b). Lean production: literature review and trends. International Journal of Production Research, 53(3), 867-885. https://doi.org/10.1080/00207543.2014.937508

Jasti, N.V.K., \& Kodali, R. (2014). A literature review of empirical research methodology in lean manufacturing. International Journal of Operations \& Production Management, 34(8), 1080-1122. https://doi.org/10.1108/IJOPM-042012-0169

Krafcik, J.F. (1988). Triumph of the lean production system. MIT Sloan Management Review, 30(1), 41.

Kolberg, D., Knobloch, J., \& Zühlke, D. (2017). Towards a lean automation interface for workstations. International Journal of Production Research, 55(10), 2845-2856. https://doi.org/10.1080/00207543.2016.1223384

Langstrand, J., \& Drotz, E. (2016). The rhetoric and reality of Lean: a multiple case study. Total Quality Management \& Business Excellence, 27(3-4), 398-412. https://doi.org/10.1080/14783363.2015.1004307

Laureani, A., \& Antony, J. (2019). Leadership and Lean Six Sigma: a systematic literature review. Total Quality Management \& Business Excellence, 30(1-2), 53-81. https://doi.org/10.1080/14783363.2017.1288565

Longoni, A., \& Cagliano, R. (2015). Cross-functional executive involvement and worker involvement in lean manufacturing and sustainability alignment. International Journal of Operations \& Production Management, 35(9), $1332-1358$. https://doi.org/10.1108/IJOPM-02-2015-0113

Ma, J., Wang, K., \& Xu, L. (2011). Modelling and analysis of workflow for lean supply chains. Enterprise Information Systems, 5(4), 423-447. https://doi.org/10.1080/17517575.2011.580007

Marinov, M., \& Marinova, S. (Eds.). (2012). Emerging economies and firms in the global crisis. Palgrave Macmillan. https://doi.org/10.1057/9781137277473 
Marodin, G.A., \& Saurin, T.A. (2013). Implementing lean production systems: research areas and opportunities for future studies. International Journal of Production Research, 51(22), 6663-6680.

https://doi.org/10.1080/00207543.2013.826831

Mehrsai, A., Thoben, K.D., \& Scholz-Reiter, B. (2014). Bridging lean to agile production logistics using autonomous carriers in pull flow. International Journal of Production Research, 52(16), 4711-4730.

https://doi.org/10.1080/00207543.2013.865851

Mejza, M., Laosirihongthong, T., \& Prajogo, D.I. (2013). An analysis of Japanese versus American automakers’ supplier relationships in Thailand. Transportation Journal, 52(2), 209-233.

https://doi.org/10.5325/transportationj.52.2.0209

Moyano-Fuentes, J., \& Sacristán-Díaz, M. (2012). Learning on lean: a review of thinking and research. International Journal of Operations \& Production Management, 32(5), 551-582. https://doi.org/10.1108/01443571211226498

Mrugalska, B., \& Wyrwicka, M.K. (2017). Towards lean production in industry 4.0. Procedia Engineering, 182, 466-473. https://doi.org/10.1016/j.proeng.2017.03.135

Mukherjee, A., \& Sastry, T. (1996). Automotive industry in emerging economies: A comparison of South Korea, Brazil, China and India. Economic and Political Weekly, M75-M78.

Mulrow, C.D. (1994). Systematic reviews: rationale for systematic reviews. Bmj, 309(6954), 597-599. https://doi.org/10.1136/bmj.309.6954.597

Narayanamurthy, G., \& Gurumurthy, A. (2016). Leanness assessment: a literature review. International Journal of Operations \& Production Management, 36(10), 1115-1160. https:/ / doi.org/10.1108/IJOPM-01-2015-0003

Narayanamurthy, G., Gurumurthy, A., \& Chockalingam, R. (2017). Applying lean thinking in an educational institute-an action research. International Journal of Productivity and Performance Management, 66(5), 598-629. https://doi.org/10.1108/IJPPM-07-2016-0144

Näslund, D. (2008). Lean, six sigma and lean sigma: fads or real process improvement methods?. Business Process Management Journal, 14(3), 269-287. https://doi.org/10.1108/14637150810876634

Negrão, L.L.L., Godinho-Filho, M., \& Marodin, G. (2017). Lean practices and their effect on performance: a literature review. Production Planning \& Control, 28(1), 33-56. https://doi.org/10.1080/09537287.2016.1231853

Nordin, N., Deros, B.M., \& Wahab, D.A. (2011). Lean manufacturing implementation in Malaysian automotive industry: An exploratory study. Operations and Supply Chain Management, 4(1), 21-30. https://doi.org/10.31387/oscm090053

Pakdil, F., \& Leonard, K.M. (2015). The effect of organizational culture on implementing and sustaining lean processes. Journal of Manufacturing Technology Management, 26(5), 725-743. https://doi.org/10.1108/JMTM-08-20130112

Panizzolo, R., Garengo, P., Sharma, M.K., \& Gore, A. (2012). Lean manufacturing in developing countries: evidence from Indian SMEs. Production Planning \& Control, 23(10-11), 769-788.

https://doi.org/10.1080/09537287.2011.642155

Papadopoulou, T.C., \& Özbayrak, M. (2005). Leanness: experiences from the journey to date. Journal of Manufacturing Technology Management, 16(7), 784-807. https://doi.org/10.1108/17410380510626196

Pettersen, J. (2009). Defining lean production: some conceptual and practical issues. The TQM journal, 21(2), 127-142. https://doi.org/10.1108/17542730910938137

Piercy, N., \& Rich, N. (2015). The relationship between lean operations and sustainable operations. International Journal of Operations \& Production Management, 35(2), 282-315. https://doi.org/10.1108/IJOPM-03-2014-0143

Pilkington, A., \& Fitzgerald, R. (2006). Operations management themes, concepts and relationships: a forward retrospective of IJOPM. International Journal of Operations \& Production Management, 26(11), 1255-1275.

https://doi.org/10.1108/01443570610705854 
Priyono, A., \& Idris, F. (2018). Analysing the adoption of Lean production in remanufacturing industry. Journal of Industrial Engineering and Management, 11(4), 697-714. https://doi.org/10.3926/jiem.2614

Raj, D., Ma, Y.J., Gam, H.J., \& Banning, J. (2017). Implementation of lean production and environmental sustainability in the Indian apparel manufacturing industry: a way to reach the triple bottom line. International Journal of Fashion Design, Technology and Education, 10(3), 254-264. https:/ / doi.org/10.1080/17543266.2017.1280091

Ram-Matawale, C., Datta, S., \& Sankar-Mahapatra, S. (2014). Leanness estimation procedural hierarchy using interval-valued fuzzy sets (IVFS). Benchmarking: An International Journal, 21(2), 150-183. https://doi.org/10.1108/BIJ03-2012-0020

Samuel, D., Found, P., \& Williams, S.J. (2015). How did the publication of the book The Machine That Changed The World change management thinking? Exploring 25 years of lean literature. International Journal of Operations \& Production Management, 35(10), 1386-1407. https://doi.org/10.1108/IJOPM-12-2013-0555

Satolo, E.G., Hiraga, L.E.D.S., Goes, G.A., \& Lourenzani, W.L. (2017). Lean production in agribusiness organizations: multiple case studies in a developing country. International Journal of Lean Six Sigma, 8(3), 335-358. https://doi.org/10.1108/IJLSS-03-2016-0012

Saurin, T.A., Rooke, J., \& Koskela, L. (2013). A complex systems theory perspective of lean production. International Journal of Production Research, 51(19), 5824-5838. https://doi.org/10.1080/00207543.2013.796420

Secchi, R., \& Camuffo, A. (2019). Lean implementation failures: The role of organizational ambidexterity. International Journal of Production Economics, 210, 145-154. https://doi.org/10.1016/j.ijpe.2019.01.007

Shah, R., \& Ward, P.T. (2003). Lean manufacturing: context, practice bundles, and performance. Journal of operations management, 21(2), 129-149. https://doi.org/10.1016/S0272-6963(02)00108-0

Shah, R., \& Ward, P.T. (2007). Defining and developing measures of lean production. Journal of operations management, 25(4), 785-805. https://doi.org/10.1016/j.jom.2007.01.019

Singh, B., Garg, S.K., \& Sharma, S.K. (2010). Development of index for measuring leanness: study of an Indian auto component industry. Measuring Business Excellence, 14(2), 46-53. https://doi.org/10.1108/13683041011047858

Sisson, J., \& Elshennawy, A. (2015). Achieving success with Lean: An analysis of key factors in Lean transformation at Toyota and beyond. International Journal of Lean six sigma, 6(3), 263-280. https://doi.org/10.1108/IJLSS-07-20140024

Slack, N., Lewis, M., \& Bates, H. (2004). The two worlds of operations management research and practice: can they meet, should they meet?. International Journal of Operations \& Production Management, 24(4), 372-387. https://doi.org/10.1108/01443570410524640

Stentoft-Arlbjørn, J., Vagn-Freytag, P., \& de Haas, H. (2011). Service supply chain management: A survey of lean application in the municipal sector. International Journal of Physical Distribution \& Logistics Management, 41(3), $277-295$. https://doi.org/10.1108/09600031111123796

Stone, K.B. (2012). Four decades of lean: a systematic literature review. International Journal of Lean Six Sigma, 3(2), 112-132. https://doi.org/10.1108/20401461211243702

Szirmai, A. (2009). Is manufacturing still the main engine of growth in developing countries. WIDER Angle newsletter, United Nations University, World Institute for Development Economics Research.

Taj, S., \& Morosan, C. (2011). The impact of lean operations on the Chinese manufacturing performance. Journal of manufacturing technology management, 22(2), 223-240. https://doi.org/10.1108/17410381111102234

Thornton, P. (2010). The global manufacturing sector: current issues. Chartered Institute of Management Accountants. Available at: http://www.cimaglobal.com/Thought-leadership/Research-topics/Managementaccounting-in-differentsectors/The-global-manufacturing-sector-current-issues/

Tiamaz, Y., \& Souissi, N. (2019). A domain model for capturing knowledge of the Lean approach. Journal of Industrial Engineering and Management, 12(1), 83-96. https:/ / doi.org/10.3926/jiem.2660 
Tortorella, G.L., Marodin, G.A., Fettermann, D.D.C., \& Fogliatto, F.S. (2016). Relationships between lean product development enablers and problems. International Journal of Production Research, 54(10), 2837-2855.

https://doi.org/10.1080/00207543.2015.1106020

Tortorella, G.L., Marodin, G.A., Fogliatto, F.S., \& Miorando, R. (2015). Learning organisation and human resources management practices: an exploratory research in medium-sized enterprises undergoing a lean implementation. International Journal of Production Research, 53(13), 3989-4000. https://doi.org/10.1080/00207543.2014.980462

Tortorella, G.L., Miorando, R., \& Tlapa, D. (2017). Implementation of lean supply chain: an empirical research on the effect of context. The TQM Journal, 29(4), 610-623. https://doi.org/10.1108/TQM-11-2016-0102

Tortorella, G.L., \& Fettermann, D. (2018). Implementation of Industry 4.0 and lean production in Brazilian manufacturing companies. International Journal of Production Research, 56(8), 2975-2987. https://doi.org/10.1080/00207543.2017.1391420

Uhrin, Á., Bruque-Cámara, S., \& Moyano-Fuentes, J. (2017). Lean production, workforce development and operational performance. Management Decision, 55(1), 103-118. https:/ / doi.org/10.1108/MD-05-2016-0281

Vinodh, S., \& Kumar-Chintha, S. (2011). Application of fuzzy QFD for enabling leanness in a manufacturing organisation. International Journal of Production Research, 49(6), 1627-1644. https://doi.org/10.1080/00207540903568729

Voss, C., \& Tsikriktsis, F.M. (2002), Case Research in operations management. International Journal of Operations \& Production Management, 22(2), 195-219. https://doi.org/10.1108/01443570210414329

Wasti, S.N., \& Liker, J.K. (1999). Collaborating with suppliers in product development: a US and Japan comparative study. IEEE Transactions on Engineering Management, 46(4), 444-460. https:/ / doi.org/10.1109/17.797966

Womack, J.P., Jones, D.T., \& Roos, D. (1990). Machine that changed the world. Simon and Schuster.

Worley, J.M., \& Doolen, T.L. (2015). Organizational structure, employee problem solving, and lean implementation. International Journal of Lean Six Sigma, 6(1), 39-58. https://doi.org/10.1108/IJLSS-12-2013-0058

Yadav, V., Jain, R., Mittal, M.L., Panwar, A., \& Sharma, M.K. (2019). An appraisal on barriers to implement lean in SMEs. Journal of Manufacturing Technology Management, 30(1), 195-212. https:/ /doi.org/10.1108/JMTM-12-2017-0262

Journal of Industrial Engineering and Management, 2019 (www.jiem.org)

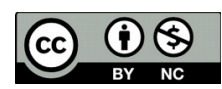

Article's contents are provided on an Attribution-Non Commercial 4.0 Creative commons International License. Readers are allowed to copy, distribute and communicate article's contents, provided the author's and Journal of Industrial Engineering and Management's names are included. It must not be used for commercial purposes. To see the complete license contents, please visit https://creativecommons.org/licenses/by-nc/4.0/. 